\title{
Spontaneous Imbibition Test of Low Salinity Injection at Low Saline Waxy Crude Carbonate
}

\author{
Fiki Hidayat ${ }^{1}$, Tomi Erfando ${ }^{1}$, Borry F Maulana ${ }^{1}$ \\ ${ }^{1}$ Department of Petroleum Engineering, Universitas Islam Riau
}

\begin{abstract}
Low salinity waterflooding (LSW) is categorized as one of emerging EOR technologies. It is done by injecting water with different salt composition and/or concentration. The research has been carried out for both sandstone and carbonate with the results looks promising. However, most of this research still concentrated in the north sea, middle east and North America region. This article discusses the applicability of low salinity waterflooding methodology in Indonesia. Spontaneous imbibition test is carried out to observe the recovery gain from a various combination of concentration and composition of the injected brine. The change of $\mathrm{pH}$ of the brine is also examined in order to confirm the $\mathrm{pH}$ effect mechanism. Three different concentration of brine (500 ppm, $5.000 \mathrm{ppm}$, and $10.000 \mathrm{ppm}$ ), three different brine composition $\left(\mathrm{NaCl}, \mathrm{CaCl}_{2}\right.$, and $\left.\mathrm{MgCl}_{2}\right)$ and high paraffinic crude oil are used as the fluid sample. It is found that the increased oil recovery is significant at a salinity of 10,000 ppm for $\mathrm{MgCl}_{2}$ and 5,000 ppm for $\mathrm{NaCl}$ ions. While the lowest recovery was shown by the test at a salinity of 500 ppm
\end{abstract}

Keywords: low salinity waterflooding, paraffinic crude oil, spontaneous imbibition, carbonate.

Corresponding Author: fikihidayat@eng.uir.ac.id

\section{INTRODUCTION}

The application of enhanced oil recovery (EOR) methods has been proposed since the early 1970s (Muggeridge et al., 2014). Muggeridge et al. (2014) divided EOR processes into two categories; traditional EOR technologies and emerging EOR technologies. Low salinity waterflooding is classified as one of the emerging technologies. Low salinity waterflooding is the development of a waterflooding method by controlling the water salinity level and its constituent component (Kokal \& Al-Kaabi, 2010). Morrow and Buckley (2011) conduct research using a brine with same brine salinity level and ion composition between connate brine and injected brine. The result shows that low salinity brine can increase oil recovery. Other researches also show similar results both in sandstone reservoir (Aladasani, 2012; Fattahi, 2014; Romero, Gamage, Jiang, Chopping, \& Thyne, 2013; Tang, 1997; Wickramathilaka, Morrow, \& Howard, 2010) and carbonate reservoir (Hamouda \& Gupta, 2017; Mahani et al., 2015; Yousef, Al-Saleh, \& Al-Jawfi, 2011; Yousef, Al-Saleh, Al-Kaabi, \& Al-Jawfi, 2011; Zhang, Tweheyo, \& Austad, 2007).

Low Salinity Water (LSW) mechanisms for sandstone are fine migration or permeability reduction, $\mathrm{pH}$ effect, and Multicomponent Ion Exchange (MIE), meanwhile, for carbonate stone, the dominant mechanisms are MIE and wettability alteration (Sheng, 2014). Oil recovery improvement at LSW method effecting by wettability alteration of carbonate stone from low water wetness become strong water wetness. Wettability alteration depend on brine ion composition such as $\mathrm{Na}^{+}, \mathrm{Ca}^{2+}$, dan $\mathrm{Mg}^{2+}$. Other research in carbonate stone with chalk surface show that $\mathrm{Mg}^{2+}$ can increase oil recovery more than $\mathrm{Ca}^{2+}$ and $\mathrm{Na}^{+}$(Zhang et al., 2007). Austad, RezaeiDoust, and Puntervold (2010) mention that replacing the power of cation shows the same thing. There is a different wettability alteration mechanism for carbonate stone at a different temperature. At lower temperature $\mathrm{Ca}^{2+}$ absorbed by the carboxylic group $\left(-\mathrm{COO}^{-}\right)$and released from the surface. At the highest temperature, $\mathrm{Mg}^{2+}$ replace $\mathrm{Ca}^{2+}$ carbocyclic complex. This mechanism occurs at spontaneous imbibition test at carbonate stone at chalk surface (Zhang et al., 2007). Meanwhile, the increase of $\mathrm{pH}$ of the brine after test shows that there is an addition of clay mineral and ion $\mathrm{Ca}^{2+}$ at injected brine (Aksulu, Håms $\varnothing$, Strand, Puntervold, \& Austad, 2012).

Numerous works of EOR have been executed in order to bring the extra oil from the reservoir in Indonesia. Abdurrahman, Permadi, Bae, and Masduki (2017) stated that the EOR technologies have been deployed in form 
of a laboratory experiment, field trial, as well as full commercial field application. Steam injection and/or cyclic steam stimulation (Hidayat \& Abdurrahman, 2018) is the current leading and proven EOR method implemented. Chemical injection such as polymer and gels (Putra \& Temizel, 2018), Gas injection (Abdurrahman et al., 2013), Microbial, seismic vibration, and electrical EOR (Ferizal et al., 2013) methods have also been considered potential based on the results from the laboratory. Hidayat and Abdurrahman (2018) also mentioned the prospect of thermal recovery into the waxy reservoir. However, none of the current literature investigates the low salinity effect in Indonesia. Therefore, this study aims to investigate the prospect of low salinity waterflooding by using a fluid sample from Indonesia. This main focus is to utilize the low salinity waterflooding for the low saline condition of carbonate rock reservoir.

\section{METHODOLOGY}

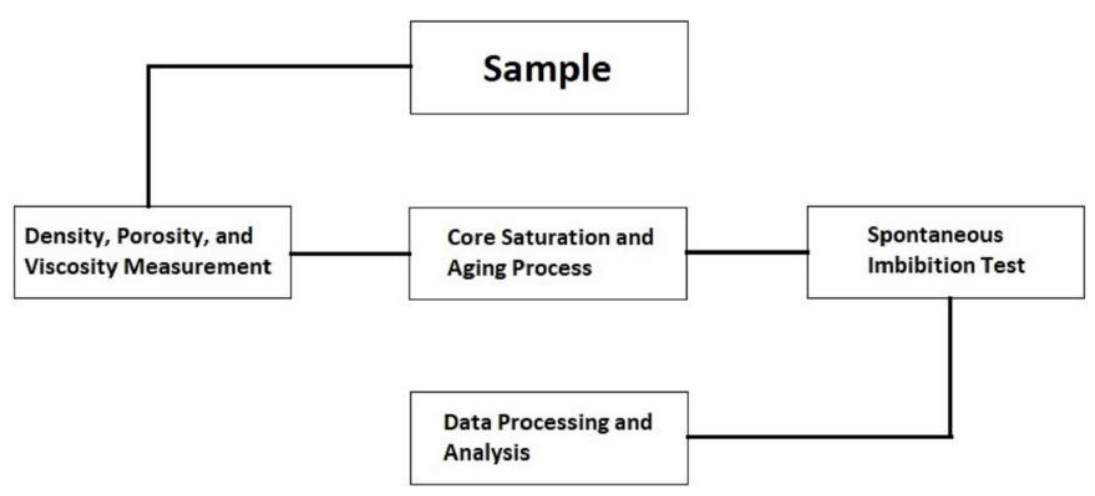

Figure 1. Procedure of Study

This study is conducted by using three different compositions of brine $\left(\mathrm{NaCl}, \mathrm{CaCl}_{2}\right.$, dan $\left.\mathrm{MgCl}_{2}\right)$ for three separate brine concentration $(500 \mathrm{ppm}, 5.000 \mathrm{ppm}$, and $10.000 \mathrm{ppm})$. The research starts from fluid sample preparation, core preparation, and spontaneous imbibition test.

The sample preparation includes making of brine composition, the measurement of crude oil sample density, and $\mathrm{pH}$ testing prior to the test. Synthetic brine was used and made by dissolving each of $\mathrm{NaCl}, \mathrm{CaCl}_{2}$, dan $\mathrm{MgCl}_{2}$ into $600 \mathrm{ml}$ of distilled water. Another required data is the density of crude oil that used to obtain the quality of sample crude oil. The data obtained are:

Table 1. Brine Solution Composition, Brine Salinity, and Oil Density

\begin{tabular}{|c|c|c|c|c|c|c|}
\hline Brine & Compound & $\begin{array}{c}\text { Mass of Salt } \\
\quad(\mathrm{mg})\end{array}$ & $\begin{array}{c}\text { Volume } \\
(\mathrm{ml})\end{array}$ & $\begin{array}{c}\text { Salinity } \\
(\mathbf{p p m})\end{array}$ & pH & $\begin{array}{c}\text { Oil } \\
\text { Density } \\
\text { (gr/cc) }\end{array}$ \\
\hline 1 & $\mathrm{NaCl}$ & 6 & 600 & 10000 & 5.5 & 0.8032 \\
\hline 2 & $\mathrm{NaCl}$ & 3 & 600 & 5000 & 5 & \\
\hline 3 & $\mathrm{NaCl}$ & 0.3 & 600 & 500 & 5 & \\
\hline 4 & $\mathrm{CaCl}_{2}$ & 6 & 600 & 10000 & 9 & \\
\hline 5 & $\mathrm{CaCl}_{2}$ & 3 & 600 & 5000 & 8.5 & \\
\hline 6 & $\mathrm{MgCl}_{2}$ & 0.3 & 600 & 500 & 5 & \\
\hline 7 & $\mathrm{MgCl}_{2}$ & 6 & 600 & 10000 & 8.5 & \\
\hline 8 & $\mathrm{MgCl}_{2}$ & 3 & 600 & 5000 & 5.5 & \\
\hline
\end{tabular}


The first step of core preparation is cleaning the core with Toluene. Soxhlet extractor is used to clean the core from other compounds such as the remnants of $\mathrm{HC}$ or water formations that contained in the core. Then, the core is dried in the vacuum oven at $100{ }^{\circ} \mathrm{C}$ until dry and weighed. The next step is to saturate the cores by using a 10,000 ppm $\mathrm{NaCl}$ brine solution. Force imbibition phenomenon on the core is simulated by using a centrifuge at 1,200 rpm for 10 minutes to get the value of saturation water connate. Finally, the core is filled with crude oil until fully saturated at $70^{\circ} \mathrm{C}$ in an oven. Aging time is required to restore core condition to its original wettability condition. The minimum time required for this aging time is 48 hours (Zhou, Torsaeter, Xie, \& Morrow, 1995).

Spontaneous imbibition tests were performed to obtain a comparison of oil recovery for each of the brine tested. This test is carried out for 24 hours and divided into 2 stages at $70^{\circ} \mathrm{C}$ by using Ammott Cell and Oven. The first stage was carried out for 12 hours using $10.000 \mathrm{ppm} \mathrm{NaCl}$ brine. The second test was carried out for 12 hours using a brine with different salinity concentration. The complete procedure of the experiment is shown in Figure 1.

\section{RESULTS}

\section{Spontaneous Imbibition Results}

The test was performed using different salinity levels. Tests were performed at salinity concentration of $500 \mathrm{ppm}$, $5,000 \mathrm{ppm}$, and $10,000 \mathrm{ppm}$. The selection of salinity is based on previous studies showing that the largest oil recovery is present at salinity 2,000 - 5,000 ppm (Mahani et al., 2015; Yousef, Al-Saleh, \& Al-Jawfi, 2011). From two testing stages obtained $R F_{12}$ (Oil Recovery Stage 1) and $R F_{24}$ (Oil Recovery Stage 2). The effect of each brine composition can be determined by comparing the differential $\mathrm{RF}\left(R F_{24}-R F_{12}\right)$ with $R F_{12}$. Figure 2 to Figure 9 shows the various results of spontaneous imbibition test. Part (a) shows the first 12 hours of the test and part (b) shows the second 12 hours of the test.

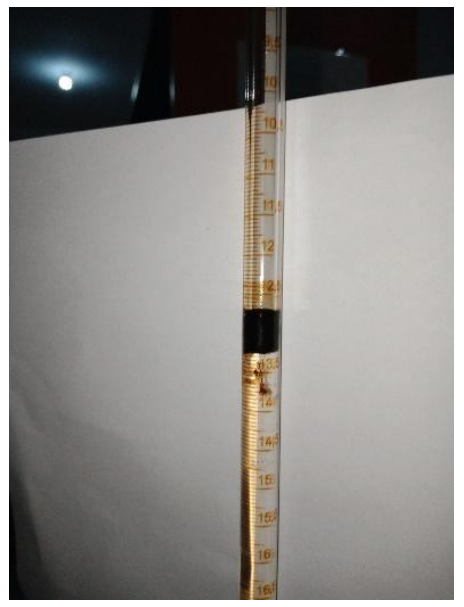

(a)

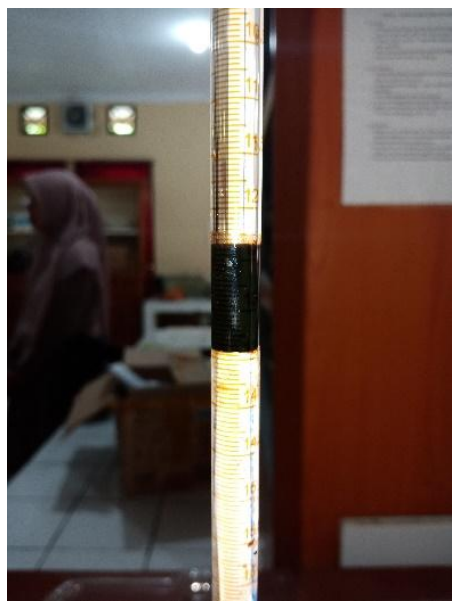

(b)

Figure 2. (a) Spontaneous imbibition test result by using $\mathrm{NaCl} 10,000 \mathrm{ppm}$ and (b) $\mathrm{NaCl} 10,000$ at second part of test 
Fiki Hidayat, Tomi Erfando, Borry Maulana/JEEE Vol. 7 No. 2/2018

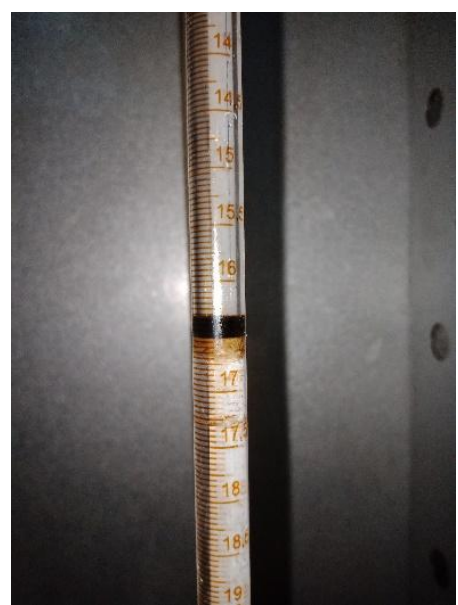

(a)

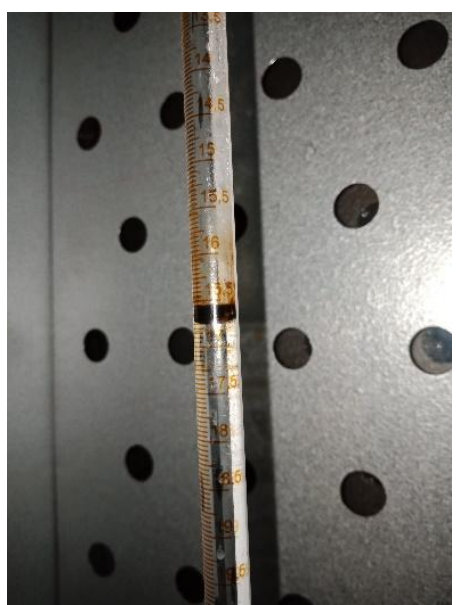

(b)

Figure 3. (a) Spontaneous imbibition test result by using $\mathrm{NaCl} 10,000 \mathrm{ppm}$ and (b) $\mathrm{CaCl}_{2} 10,000 \mathrm{ppm}$

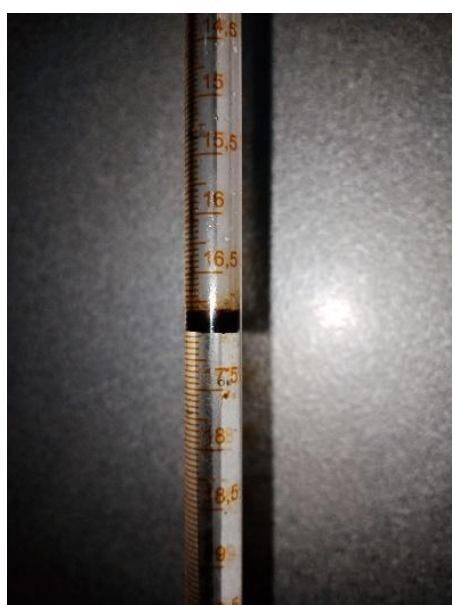

(a)

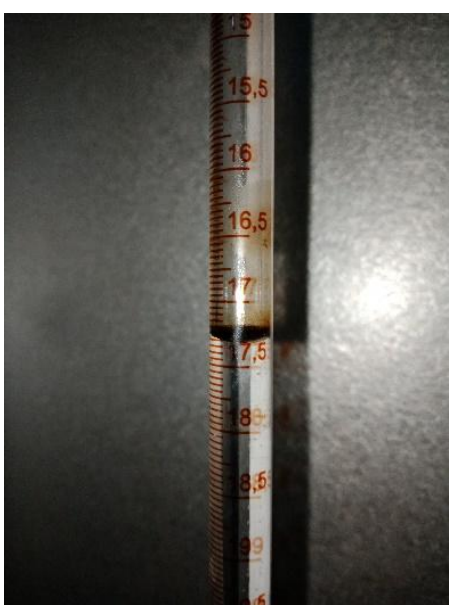

(b)

Figure 4. (a) Spontaneous imbibition test result by using $\mathrm{NaCl} 10,000 \mathrm{ppm}$ and (b) $\mathrm{MgCl}_{2} 10,000 \mathrm{ppm}$

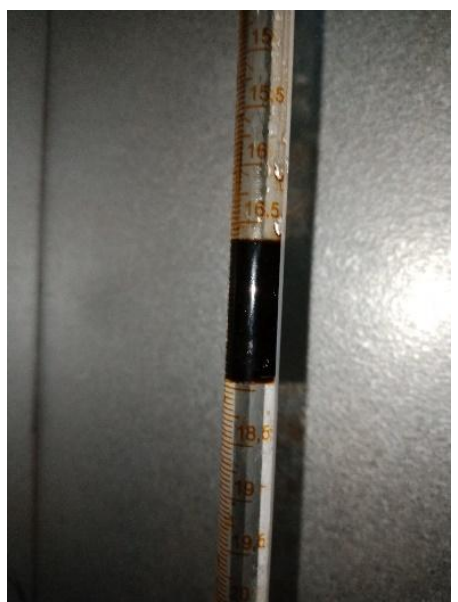

(a)

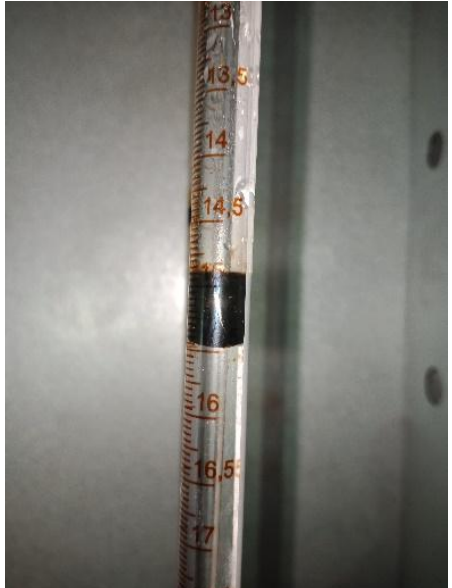

(b)

Figure 5. (a) Spontaneous imbibition test result by using $\mathrm{NaCl} 10,000 \mathrm{ppm}$ and (b) $\mathrm{NaCl}$ 5,000 ppm 
Fiki Hidayat, Tomi Erfando, Borry Maulana/JEEE Vol. 7 No. 2/2018

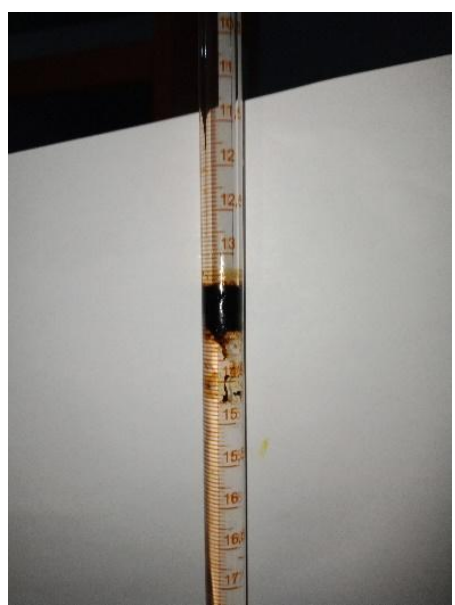

(a)

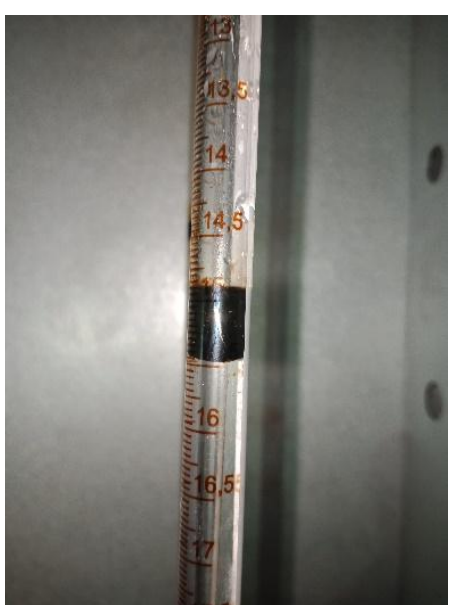

(b)

Figure 6. (a) Spontaneous imbibition test result by using $\mathrm{NaCl} 10,000 \mathrm{ppm}$ and (b) $\mathrm{CaCl}_{2} 5,000 \mathrm{ppm}$

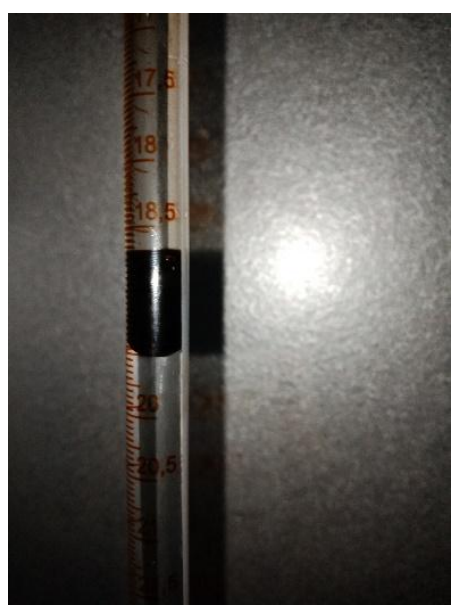

(a)

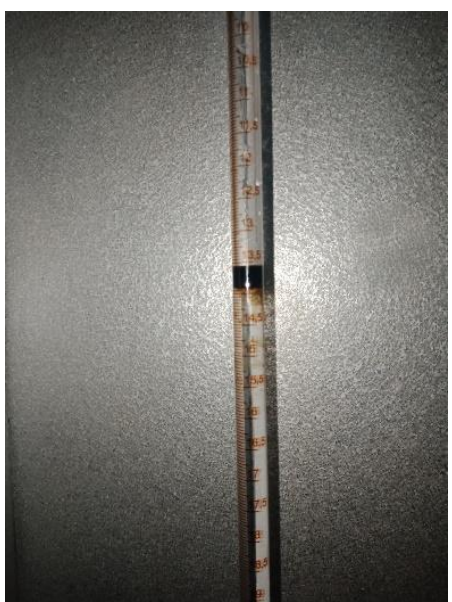

(b)

Figure 7. (a) Spontaneous imbibition test result by using $\mathrm{NaCl} 10,000 \mathrm{ppm}$ and (b) $\mathrm{MgCl}_{2} 5,000 \mathrm{ppm}$

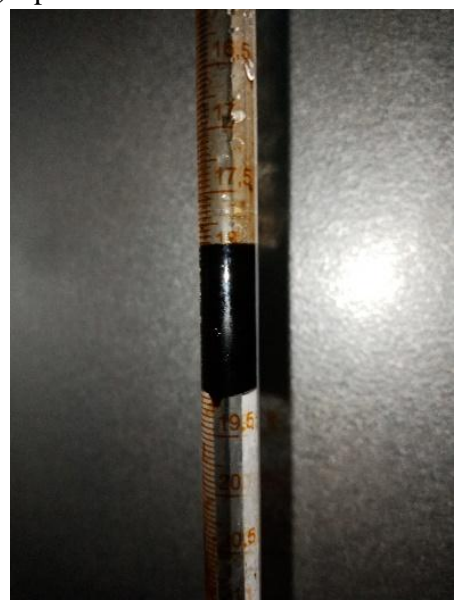

(a)

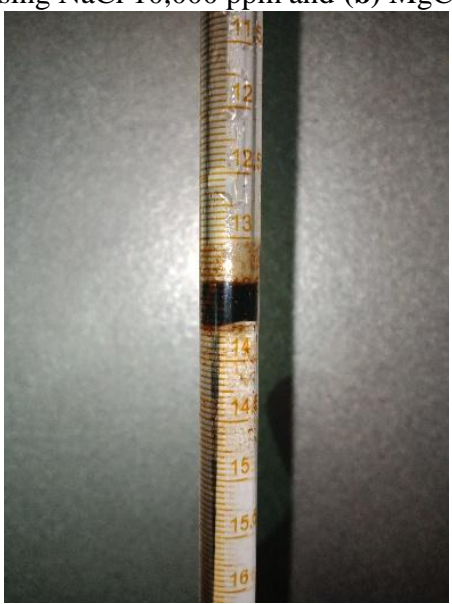

(b)

Figure 8. (a) Spontaneous imbibition test result by using $\mathrm{NaCl} 10,000 \mathrm{ppm}$ and (b) $\mathrm{NaCl} 500 \mathrm{ppm}$ 


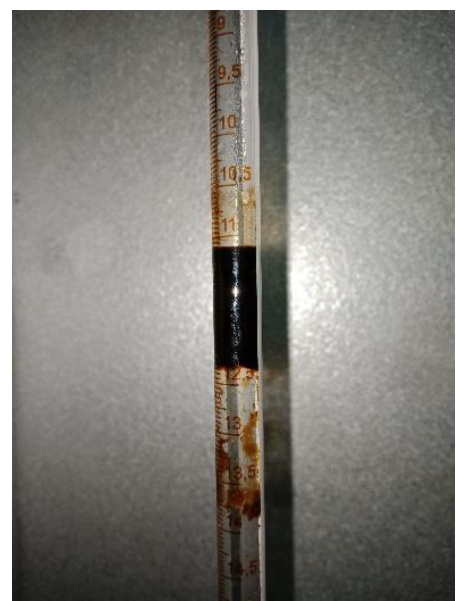

(a)

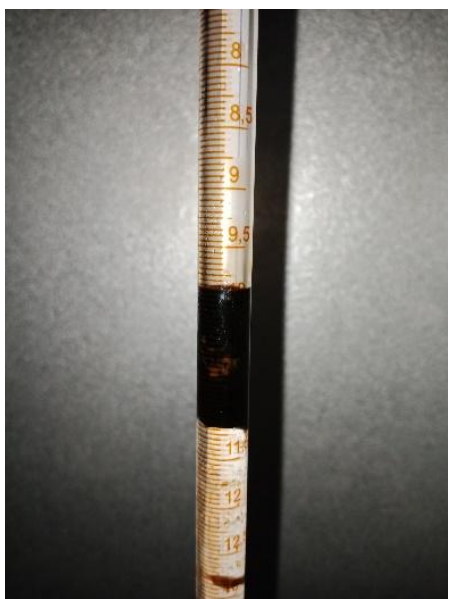

(b)

Figure 9. (a) Spontaneous imbibition test result by using $\mathrm{NaCl} 10,000 \mathrm{ppm}$ and (b) $\mathrm{CaCl}_{2} 500 \mathrm{ppm}$

\section{pH Effect}

The $\mathrm{pH}$ of the brine solution was tested at the time before and after the experiment. The $\mathrm{pH}$ measurements were performed at the beginning of spontaneous imbibition, at the turn of the brine content, and after the test was performed. From the test is obtained $\mathrm{pH}$ changes shown in Table 2 below.

Table 2. Experiment Result for pH Effect Mechanism

\begin{tabular}{ccccccc}
\hline Test & \multicolumn{2}{c}{ Injected Brine } & \multicolumn{2}{c}{ Step 1 } & \multicolumn{3}{c}{ Step 2 } \\
\cline { 2 - 7 } & Step 1 & Step 2 & Early & Later & Early & Later \\
\hline $\mathbf{1}$ & $\mathrm{NaCl} 10.000 \mathrm{ppm}$ & $\mathrm{NaCl} 10.000 \mathrm{ppm}$ & 5.5 & 6 & 5.5 & 6 \\
\hline $\mathbf{2}$ & $\mathrm{NaCl} 10.000 \mathrm{ppm}$ & $\mathrm{NaCl} 5.000 \mathrm{ppm}$ & 5.5 & 6 & 5 & 6 \\
\hline $\mathbf{3}$ & $\mathrm{NaCl} 10.000 \mathrm{ppm}$ & $\mathrm{NaCl} 500 \mathrm{ppm}$ & 5.5 & 6 & 5 & 6 \\
\hline $\mathbf{4}$ & $\mathrm{NaCl} 10.000 \mathrm{ppm}$ & $\mathrm{CaCl}_{2} 10.000 \mathrm{ppm}$ & 5.5 & 6 & 9 & 10 \\
\hline $\mathbf{5}$ & $\mathrm{NaCl} 10.000 \mathrm{ppm}$ & $\mathrm{CaCl}_{2} 5.000 \mathrm{ppm}$ & 5.5 & 6 & 8.5 & 9 \\
\hline $\mathbf{6}$ & $\mathrm{NaCl} 10.000 \mathrm{ppm}$ & $\mathrm{CaCl}_{2} 500 \mathrm{ppm}$ & 5.5 & 6 & 5 & 6 \\
\hline $\mathbf{7}$ & $\mathrm{NaCl} 10.000 \mathrm{ppm}$ & $\mathrm{MgCl}_{2} 10.000 \mathrm{ppm}$ & 5.5 & 6 & 8.5 & 9.5 \\
\hline $\mathbf{8}$ & $\mathrm{NaCl} 10.000 \mathrm{ppm}$ & $\mathrm{MgCl}_{2} 5.000 \mathrm{ppm}$ & 5.5 & 6 & 5.5 & 6 \\
\hline
\end{tabular}


Fiki Hidayat, Tomi Erfando, Borry Maulana/JEEE Vol. 7 No. 2/2018

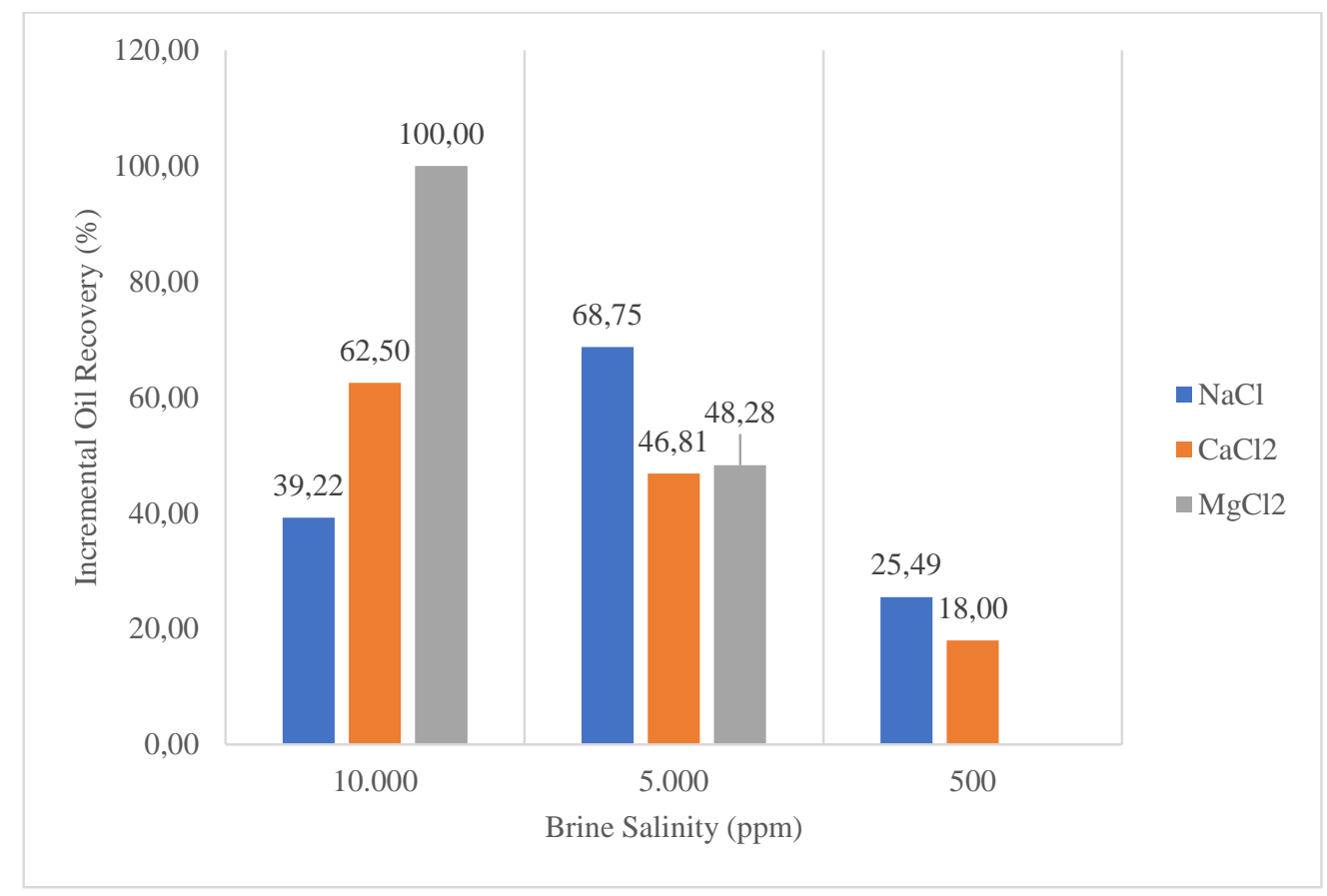

Figure 10. Comparison of Incremental $R F$ to Initial $R F$

\section{DISCUSSION}

Aksulu et al. (2012) states that the changes of $\mathrm{pH}$ levels in the carbonate rocks are due to an increase in cation content of $\mathrm{Ca}^{2+}$ and clay minerals in brine which also occurs in sandstone rocks. In this experiment, the change of $\mathrm{pH}$ is in the region of 0.5 to 1 . The addition of $\mathrm{pH}$ proves that multicomponent ion exchange are the mechanisms that cause wettability alteration in carbonate rocks and are the mechanisms that lead to an increased recovery in carbonate rock.

Fig.10 shows the effect of various brine composition and concentration of salinity tested. There is a different trend between $\mathrm{NaCl}$ with $\mathrm{CaCl}_{2}$ and $\mathrm{MgCl}_{2}$. The lowest incremental recovery was obtained at the test with a salinity of $5,000 \mathrm{ppm}$ and $500 \mathrm{ppm}$. Whereas brine $\mathrm{CaCl}_{2}$ and $\mathrm{MgCl}_{2}$ showing better reaction at a salinity of $10,000 \mathrm{ppm}$. This difference suggests that the ionic capacity of brine as a substitute for cations in the MIE mechanism is strongly influenced by saline connate brine. In this test, the $\mathrm{NaCl}$ works more effectively when the injected brine has a lower concentration of salinity than connate brine. While $\mathrm{CaCl}_{2}$ and $\mathrm{MgCl}_{2}$ are more effective in producing oil if injected brine has the same concentration as connate brine.

In addition, Fig. 10. also shows that at a salinity of $10,000 \mathrm{ppm} \mathrm{MgCl}_{2}$ is the best-replacing brine. $\mathrm{The} \mathrm{MgCl}_{2}$ can increase the recovery factor by $100,00 \%$. While the $\mathrm{NaCl}$ and $\mathrm{CaCl}_{2}$ can only increase the recovery factor by $39.22 \%$ and $62,50 \%$, respectively. For spontaneous imbibition tests at $5,000 \mathrm{ppm}$ and $500 \mathrm{ppm}, \mathrm{NaCl}$ works better than $\mathrm{CaCl}_{2}$ and $\mathrm{MgCl}_{2}$ with the incremental recovery factor of $68.75 \%$ and $25.49 \%$ respectively.

\section{CONCLUSION}

- This experiment was conducted to determine the effect of each ion on increasing oil recovery for different salinity levels

- Increased oil recovery is significant at a salinity of $10,000 \mathrm{ppm}$ for $\mathrm{MgCl}_{2}$ and 5,000 ppm for $\mathrm{NaCl}$ ions. While the lowest recovery was shown by the test at a salinity of $500 \mathrm{ppm}$.

- The $\mathrm{pH}$ changes in each test performed indicating the presence of the MIE mechanism. 
Fiki Hidayat, Tomi Erfando, Borry Maulana/JEEE Vol. 7 No. 2/2018

- $\mathrm{NaCl}$ works better when the concentration is lower than connate brine, whereas $\mathrm{CaCl}_{2}$ and $\mathrm{MgCl}_{2}$ react better at the same salinity.

\section{Acknowledgments}

This research was supported by Direktorat Riset dan Pengabdian Masyarakat Direktorat Jenderal Penguatan Riset dan Pengembangan Kementerian Riset, Teknologi, dan Pendidikan Tinggi with contract no: 135/KONTRAK/LPPM/2-2018. Author also wish to thank Universitas Islam Riau (UIR), Indonesia, for the encouragement of writing this paper.

\section{References}

Abdurrahman, M., Bae, W., Permadi, A. K., Am, S., Gunadi, B., Saputra, D. D. S. M., . . Gunadi, T. A. (2013). Opportunities and Challenges of CO2 Flooding Implementation in Indonesia. Paper presented at the SPE Asia Pacific Oil and Gas Conference and Exhibition, Jakarta, Indonesia. https://doi.org/10.2118/165847MS

Abdurrahman, M., Permadi, A. K., Bae, W., \& Masduki, A. (2017). EOR in Indonesia- past present and future. Int. J. Oil, Gas and Coal Technology, 16(3), 250-270.

Aksulu, H., Håms $\varnothing$, D., Strand, S., Puntervold, T., \& Austad, T. (2012). Evaluation of Low-Salinity Enhanced Oil Recovery Effects in Sandstone: Effects of the Temperature and pH Gradient. Energy \& Fuels, 26(6), 34973503. doi:10.1021/ef300162n

Al-Yaari, M. (2011). Paraffin Wax Deposition: Mitigation \& Removal Techniques. Paper presented at the SPE Saudi Arabia Section Young Professionals Technical Symposium, Dhahran, Saudi Arabia.

Aladasani, A. B., Baojun; Wu, Yu-Shu. (2012). Investigating Low-Salinity Waterflooding Recovery Mechanisms in Sandstone Reservoirs. Paper presented at the SPE Improved Oil Recovery Symposium, Tulsa, Oklahoma.

Austad, T., RezaeiDoust, A., \& Puntervold, T. (2010). Chemical mechanism of low salinity water flooding in sandstone reservoirs. Paper presented at the SPE improved oil recovery symposium.

Fattahi, A. (2014). Low Salinity Waterflooding in sandstone-A Review. International Journal of Petroleum Geoscience Engineering, 2(4), 315-341.

Ferizal, F. H., Netzhanova, A. A., Lee, J., Bae, W., Am, S., \& Gunadi, T. A. (2013). Revitalizing Indonesia's Potential for Oil Production: The Study of Electromagnetically Heated Gravel Packs for Steam-produced Heavy Oil Reservoirs. Paper presented at the SPE Heavy Oil Conference-Canada, Calgary, Alberta, Canada. https://doi.org/10.2118/165508-MS

Hamouda, A. A., \& Gupta, S. (2017). Enhancing oil recovery from chalk reservoirs by a low-salinity water flooding mechanism and fluid/rock interactions. Energies, 10(4), 576.

Hidayat, F., \& Abdurrahman, M. (2018). A Prospective Method to Increase Oil Recovery in Waxy-Shallow Reservoir. IOP Conference Series: Materials Science and Engineering, 306(1), 012040.

Kokal, S., \& Al-Kaabi, A. (2010). Enhanced oil recovery: challenges \& opportunities. World Petroleum Council: Official Publication, 64.

Mahani, H., Keya, A. L., Berg, S., Bartels, W.-B., Nasralla, R., \& Rossen, W. (2015). Driving mechanism of low salinity flooding in carbonate rocks. Paper presented at the EUROPEC 2015.

Morrow, N., \& Buckley, J. (2011). Improved oil recovery by low-salinity waterflooding. Journal of Petroleum Technology, 63(05), 106-112.

Muggeridge, A., Cockin, A., Webb, K., Frampton, H., Collins, I., Moulds, T., \& Salino, P. (2014). Recovery rates, enhanced oil recovery and technological limits. Philos Trans A Math Phys Eng Sci, 372(2006), 20120320. doi:10.1098/rsta.2012.0320

Putra, D. F., \& Temizel, C. (2018). The Optimization and Analysis of Hydrocarbon Recovery under Injection of Biopolymer, Synthetic Polymer and Gels in a Heterogeneous Reservoir. Journal of Earth Energy Engineering, 7(1), 19-41. doi:10.25299/jeee.2018.vol7(1).1301 
Romero, M. I., Gamage, P., Jiang, H., Chopping, C., \& Thyne, G. (2013). Study of low-salinity waterflooding for single- and two-phase experiments in Berea sandstone cores. Journal of Petroleum Science and Engineering, 110, 149-154. doi:10.1016/j.petrol.2013.08.050

Sheng, J. J. (2014). Critical review of low-salinity waterflooding. Journal of Petroleum Science and Engineering, 120, 216-224. doi:10.1016/j.petrol.2014.05.026

Tang, G. Q. M., N. (1997). Salinity, Temperature, Oil Composition, and Oil Recovery by Waterflooding. SPE Reservoir Engineering, 269-276.

Wickramathilaka, S., Morrow, N. R., \& Howard, J. (2010). Effect of salinity on oil recovery by spontaneous imbibition. Paper presented at the 24th International Symposium of Core Analysts, Halifax, Canada.

Yousef, A. A., Al-Saleh, S., \& Al-Jawfi, M. S. (2011). Smart waterFlooding for carbonate reservoirs: Salinity and role of ions. Paper presented at the SPE middle east oil and gas show and conference.

Yousef, A. A., Al-Saleh, S. H., Al-Kaabi, A., \& Al-Jawfi, M. S. (2011). Laboratory investigation of the impact of injection-water salinity and ionic content on oil recovery from carbonate reservoirs. SPE Reservoir Evaluation Engineering, 14(05), 578-593.

Zhang, P., Tweheyo, M. T., \& Austad, T. (2007). Wettability alteration and improved oil recovery by spontaneous imbibition of seawater into chalk: Impact of the potential determining ions $\mathrm{Ca} 2+, \mathrm{Mg} 2+$, and $\mathrm{SO} 42-$. Colloids Surfaces A: Physicochemical Engineering Aspects, 301(1-3), 199-208.

Zhou, X.-m., Torsaeter, O., Xie, X., \& Morrow, N. (1995). The effect of crude-oil aging time and temperature on the rate of water imbibition and long-term recovery by imbibition. SPE Formation Evaluation, 10(04), 259-266. 